\title{
Pathogenicity of Fusarium species associated with crown and root rot of wheat (Triticum aestivum) under different condition
}

Patogenicidad de especies de Fusarium asociados a daño del ápice y la raíz del trigo (Triticum aestivum) bajo diferentes condiciones

Author:

Bareen Sidqi Shareef Al-Tovi ${ }^{1}$

Raed Abduljabbar Haleem ${ }^{2}$

\section{SCIENTIFIC RESEARCH}

How to cite this paper:

Al-Tovi B S S., and Haleem R. A., Pathogenicity of Fusarium species associated with crown and root rot of wheat (Triticum aestivum ) under different condition. Innovaciencia. 2019; 7 (1): 1-9.

http://dx.doi.org/10.15649/2346075X.659

Reception date:

Received: 15 January 2019

Accepted: 5 May 2019

Published: 25 October 2019

Keywords:

Fusarium species; Wheat; Pathogenicity; Invivo; In-vitro; Crown and root rot.

\section{ABSTRACT}

This study was conducted to test the pathogenicity of Fusarium species, the causes of crown and root rot disease of wheat crop, under three different conditions (Laboratory, Greenhouse and Field) and to show the best method for pathogenicity among different conditions. Pathogenicity test of six isolates of Fusarium species (F. graminearum, F. oxysporum, F. avenaceum, F. nivale, F. solani and F. udum) was tested on durum (Simeto) cultivar of wheat by test tube method in the laboratory, the tested fungi had substantial effect on seed germination. F. oxysporum showed the highest germination failure (44.44\%) which significantly differed with other species. In the greenhouse, seedlings were inoculated by spore suspension at the base of each plant stem. The most virulent fungus after 35 days of inoculation was F. oxysporum (0.78) followed by F. solani (0.70) and F. graminearum (0.66), while the lowest disease severity was recorded by $F$. udum (0.16). Also in the field pathogenicity experiments of three Fusarium species (F. graminearum, F. oxysporum and F. solani) were performed on a durum (Simeto) and soft (Cham6) cultivars. Spore suspension was applied at the 2- to 3-leaf Zadoks's growth stage. Disease severity was calculated at two stages of wheat growth (Booting and Ripening). The most virulent fungus was F. graminearum (0.42) that was significantly different from other fungi. This work indicated that F. graminearum, F. oxysporum and F. solani showed higher infection than remaining tested species under three conditions. Pathogenicity test in laboratory by test tube method (In-vitro) appeared more effective than greenhouse and field experiments

1 Plant Protection Department, College of Agriculture, University of Duhok, Duhok Province, Kurdistan Region -Iraq. E-Mail: barin.tovi89@yahoo.com.

2 Plant Protection Department, College of Agriculture, University of Duhok, Duhok Province, Kurdistan Region -Iraq. E-Mail: raed.haleem@uod.ac. 


\section{INTRODUCTION}

Fusarium species are a varied group of fungi that have an effect on cereals through rotting of seeds, root, crown, seedling, basal stem, and spike ${ }^{(1)}$. Crown rot, foot rot and root rot are economically essential diseases of cereal in various grains producing regions around the world and appear to be especially developed by dry climatic conditions $\stackrel{(2)}{2}$.Various pathogen species in the genera Fusarium cause crown and root rot disease which includes Fusarium culmorum, F. graminearum, F. equisetum. pseudograminearum, F. acuminatum, F. nivale, $F$. avenaceum, but $F$. graminearum, $F$. culmorum and F. pseudograminearum, are epidemiologically the highly important species involved in this disease ${ }^{(3)}$. This disease has been found in many regions of the world, and particularly under dry condition and caused yield losses of more than $50 \%{ }^{(4,5)}$. Wheat fungal infections caused by Fusarium species are important economically in cereal growing countries including Bulgaria ${ }^{(6)}$. In the pacific Northwest of America Paulitz et al. ${ }^{(1)}$ determined that $76 \%$ of the plants in winter wheat fields can be infected with Fusarium crown rot with estimated losses of $18 \%$ in heavily infected fields. Yield losses have been reported $25-58 \%$ in Australia, amounting to 80 million US dollars, due to reduced grain yield and quality (7). According to surveys conducted across Duhok province-Iraq, Fusarium graminearum, Fusarium oxysporum, Fusarium solani, Fusarium avenaceum, Fusarium nivale and Fusarium udum were isolated from root and crown of wheat ${ }^{(8)}$. There are other studies in Iraq identified Fusarium as a causal agent of crown and root rot (FCRR) on wheat plants $(9 ; 10,11)$. Pathogenicity of Fusarium species and its aggressiveness on wheat crop evaluate by different methods ${ }^{(12)}$ such as: seeds inoculation by putting them on inoculated

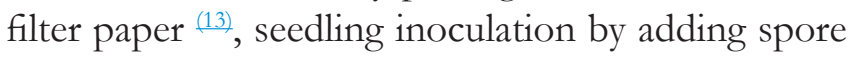
suspension to the stem ${ }^{(14)}$ or by agar plug mycelium placed next to the lower stem of seedling ${ }^{(15)}$.

This study was undertaken to investigate the virulence of Fusarium species isolated from the same location (Sumel district) causes Fusrium crown and root rot of wheat (FCRR) under different conditions (In-vitro Laboratory and greenhouse and In-vivo Field conditions).

\section{MATERIALS AND METHODS}

\section{Fungal Isolates}

Fungal isolates were obtained from crown and root of wheat randomly selected from fields surveyed at Sumel district- Duhok province during 2014-2015. Collected plants were washed thoroughly under running tap water for half hour. Crown and root was taken from each stem. These sections were surface disinfected with $1 \%$ sodium hypochlorite $(\mathrm{NaO}$ CL) for 2 minutes, rinsed twice in sterilized water, and dried on sterile filter papers. Sections was plated onto full strength potato dextrose agar (PDA) medium that made by (Himedia laboratories Pvt. Ltd.-India) 39.5g.of medium per liter of distal water mended with $250 \mathrm{mg}$ of chloramphenicol to inhibit bacterial growth sterilized by autoclave at $121^{\circ} \mathrm{C}$ for $20 \mathrm{mins}$ and $1.5 \mathrm{~kg} / \mathrm{cm}^{2}$ pressure. Plant parts were cultured on sterilized PDA with 5 pieces / plate. The plates were incubated at $25 \pm 1^{\circ} \mathrm{C}$ for 7 days under a $12 / 12 \mathrm{~h}$ photoperiod. Suspected isolates were purified, identified and transfer to fresh media. Fusarium species were identified based on their morphological characters including: colony appearance, morphology of microconidia, macroconidia, chlamydospores, and conidiophores according to Booth ${ }^{(10)}$; Nelson $e t$ al., ${ }^{(17)}$; Summerell et al., ${ }^{(18)}$; Leslie and Summerell $\stackrel{(19)}{ }$.

\section{Pathogenicity Test}

\section{Test tube method}

The pathogenic nature of six species of Fusarium (Fusarium graminearum, F. oxysporum, F. avenaceum, F. nivale, F. solani and F. udum) was tested on durum wheat cultivar (Simeto) by test tube method in the laboratory of College of Agriculture/ University of Duhok. The test tubes $(16 \mathrm{~cm} \times 2 \mathrm{~cm})$ were prepared by filling the tubes bottom with $5 \mathrm{~cm}$ of cotton. Five milliliter of distilled water was added to each tube and lids were covered with aluminum foil then autoclaved in $121^{\circ} \mathrm{C}$ and pressure $1.5 \mathrm{~kg} / \mathrm{cm}^{2}$ for $1 \mathrm{~h}$. Wheat seeds which surface disinfected by $1 \%$ of sodium hypochlorite $(\mathrm{NaOCL})$ for two minutes and washed twice in sterilized distilled water were placed on the moist cotton swab in each test tube (3seeds/ tube). Adjacent to seeds one disk of $5 \mathrm{~mm}$ of fungal isolate was placed. After inoculation again, the tubes 
were sealed with aluminum foil and were putted in incubator at $25 \pm 1{ }^{\circ} \mathrm{C}$ for incubation. This test was done according to $\stackrel{(20)}{\text {. }}$.

The tubes were arranged in complete randomized design (CRD). After two weeks, percentage of seeds germination, percentage of infection, disease severity, and the length of root and green growth were recorded using the following formula:

No. of germinated grains

$\%$ Germination $=$ $\times 100$

Total No. of grains

No. of infected seedlings

$\%$ Incidence $=$ $\times 100$

Total No. of examined seedling

Severity ratings depending on the discoloration from the roots to the crown above the soil line were assigned in the lab based on a scale scoring from 0 to 4 where:

$0=$ Healthy plant, $1=(1-10 \%)$ Brown discoloration, $2=(11-25 \%)$ Brown discoloration, $3=(26-50 \%)$ Brown discoloration, $4=(51-100 \%)$ Brown discoloration

Disease severity (DS) was estimated according to McKin-

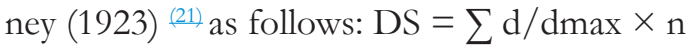

Where DS is the disease severity, $\mathrm{d}$ is (the disease rating on each plant), dmax is (the maximum disease rating possible) and $\mathrm{n}$ is (the total number of plants examined in each replicate).

\section{Pathogenicity trial of potted wheat plant under greenhouse conditions}

Pathogenicity experiment was conducted under greenhouse condition at College of Agriculture/ University of Duhok on durum (Simeto) wheat cultivar. Six Fusarium isolates (F. avenaceum, F. graminearum, F. nivale, F. oxysporum, F. solani and F. udum) were tested. Before sowing seeds in plastic pots $(12 \mathrm{~cm}$ height $\times 11 \mathrm{~cm}$ width), wheat seeds were surface disinfected by the following method: seeds were washed for $5 \mathrm{~min}$ by running tap water, immersed in $70 \%$ ethanol and in $1 \% \mathrm{NaOCl}$ for $1 \mathrm{~min}$, rinsed twice in dis- tilled water, finally seeds dried under a laminar flow hood. Seeds were sown at a depth of $2 \mathrm{~cm}$ in each pot that were filled with sterilized soil (sand and peat $2: 1)$ by autoclave $\left(121^{\circ} \mathrm{C}\right.$ and pressure $1.5 \mathrm{~kg} / \mathrm{cm}^{2}$ for 20 minutes twice). Each replicate consisted of a pot, and two seeds were planted in each. Fourteen days after planting, seedlings were inoculated at the base of the shoot using spore suspension technique $\stackrel{(22)}{2}$. A volume of $10 \mathrm{ml}$ of a spore suspension $\left(1 \times 10^{6}\right.$ spores $/ \mathrm{ml}$ ) was added at the base of each plant stem. All plants were watered daily. Disease severity and incidence of crown and root rot of each plant were assessed 35 days after inoculation $\stackrel{(22)}{2}$. The experiment was done in a Complete Randomized Design (CRD) which consisted of three replications.

\section{Pathogenicity trial of potted wheat plant under field conditions}

Pathogenicity experiments were conducted in the field of college of Agriculture/ University of Duhok on a durum (Simeto) and soft (Cham6) cultivars of wheat. Three Fusarium species (F. graminearum, F. oxysporum and F. solani) isolated during field survey were tested. Before seeds sowing in plastic pots $(25 \mathrm{x}$ $25 \mathrm{~cm}$ ), seeds were surface disinfected and air dried. Seeds were sown at a depth of $2 \mathrm{~cm}$ by 20 seeds/pot that contains field clay soil serialized by $1 \%$ Formaldehyde, accordingly the soil mixed with peat moss at $(2: 1)$. Spore suspension was prepared and applied as mentioned previously at the 2- to 3-leaf Zadoks's growth stage $\stackrel{(23)}{-}$. Inoculation was applied to four pots and plants were watered as needed.

At both stages of wheat growth (Booting and Ripening), roots and crown from 10 plants/ pot were washed and severity of crown and root rot was assessed and calculated according to Mckinney (1923) ${ }^{(21)}$.The trail was done as factorial in a Randomized Complete block Design (RCBD) with four replications.

\section{Data analysis}

Data were analyzed using Statistical Analysis System (version 8.2; SAS, 2003). Data were subjected to analysis of variance (ANOVA) and pooled together after testing the homogeneity of variance $(\mathrm{P} \leq 0.05)$. Means of the treatments were compared by Duncan Multiple Range Test at 5\% level $\stackrel{(24)}{\text {. }}$ 


\section{RESULTS}

\section{Test tube method}

In-vitro results of pathogenicity test of Fusarium graminearum, F. oxysporum, F. solani, F. avenaceum, F. nivaleand F. udum on Simeto cultivar showed the distinctive symptoms of brown to dark brown even black decaying and rotting of seeds, roots, crown area and lower stem to above; root growth and seed- ling vigor were reduced (Figure 1). Statistical analysis of pathogenicity test showed that the highest and considerable disease incidence and severity were recorded by F. oxysporum (0.56) and with no significant difference with F. solani and F. graminearum ( 0.53 and 0.50 respectively); with entirely incidence for each that significantly different with fungi (F.avenaceum and $F$. nivale). The lowest pathogenicity was shown by F. nivale (0.20 and 44.44\%) (Table 1$)$.

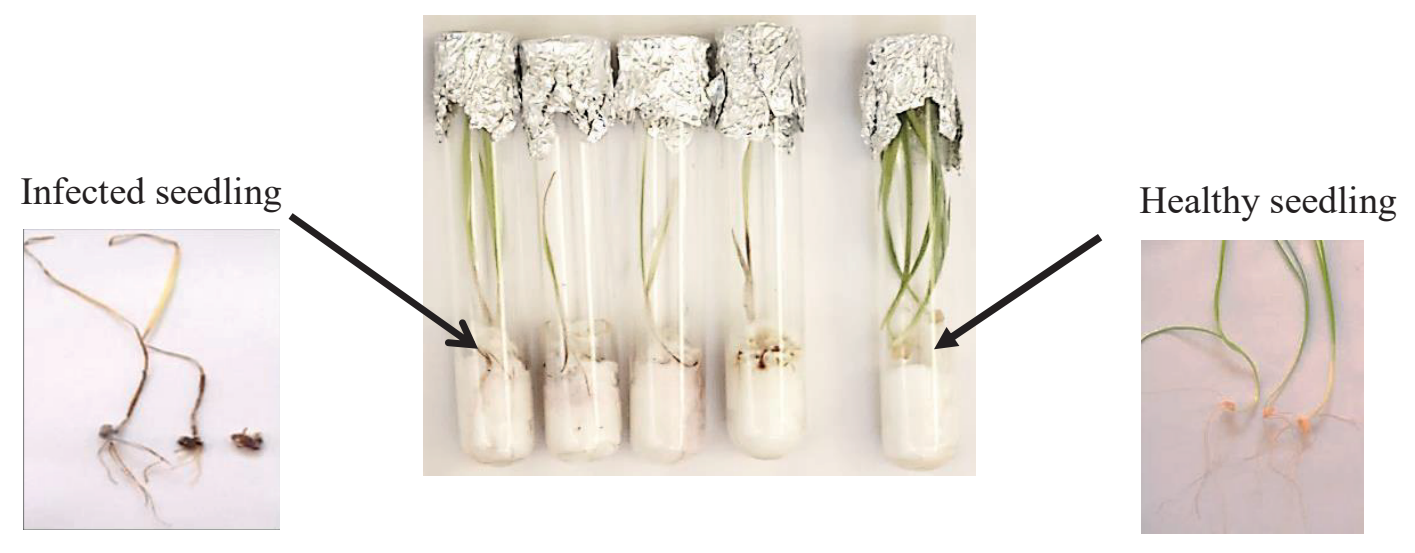

Figure 1. Pathogenicity shows of FCRR disease on wheat seedlings by test tube method.

The tested fungi had substantial effect on seed germination, F. oxysporum showed the highest germination failure $(44.44 \%)$ which significantly differed with other species. The germination rate with $F$. graminearum and F. solani were $(77.77 \%)$ for each. In contrast, wheat seeds with inoculum of $F$. nivale, $F$. udumand $F$. avenaceum germinated entirely. The most affected fungus on seedling height was F. oxysporum which was reduced its growth remarkably to $7.6 \mathrm{~cm}$. No significant difference appeared between F. gram- inearum, F. solani and F. udum $(12.5 \mathrm{~cm}, 11.97 \mathrm{~cm}$ and $12.52 \mathrm{~cm}$ respectively), $F$. avenaceum and $F$. nivale were in low effect on the wheat seedlings. The virulence of F. oxysporum progressed to root length which led to produce seedling with no or very short roots $(1.66 \mathrm{~cm})$ with significant difference with tested fungi followed by F. solani and F. graminearum, the lowest effect was caused by F. nivale $(7.16 \mathrm{~cm})$ compared to control treatment $(18.67 \mathrm{~cm})$.

Table 1. Pathogenicity test of Fuasium species and its effect on seed germination rate, seedling height and root length of wheat.

\begin{tabular}{lccccc}
\hline \multicolumn{1}{c}{ Fungi } & $\begin{array}{c}\text { Disease } \\
\text { severity }\end{array}$ & $\begin{array}{c}\text { \%Disease } \\
\text { incidence }\end{array}$ & $\%$ Germination & $\begin{array}{c}\text { Seedling } \\
\text { height(cm) }\end{array}$ & $\begin{array}{c}\text { Root } \\
\text { length(cm) }\end{array}$ \\
\hline F. graminearum & $0.50 \mathrm{a}$ & $100 \mathrm{a}$ & $77.77 \mathrm{a}$ & $12.5 \mathrm{~b}$ & $5.66 \mathrm{bc}$ \\
F. oxysporum & $0.56 \mathrm{a}$ & $100 \mathrm{a}$ & $44.44 \mathrm{~b}$ & $7.66 \mathrm{c}$ & $1.66 \mathrm{~d}$ \\
F. solani & $0.53 \mathrm{a}$ & $100 \mathrm{a}$ & $77.77 \mathrm{a}$ & $11.97 \mathrm{~b}$ & $3.55 \mathrm{~cd}$ \\
F. avenaceum & $0.26 \mathrm{~b}$ & $66.66 \mathrm{~b}$ & $100 \mathrm{a}$ & $15.99 \mathrm{a}$ & $5.66 \mathrm{bc}$ \\
F. nivale & $0.20 \mathrm{~b}$ & $44.44 \mathrm{c}$ & $100 \mathrm{a}$ & $16.66 \mathrm{a}$ & $7.16 \mathrm{~b}$ \\
F. udum & $0.21 \mathrm{~b}$ & $88.88 \mathrm{a}$ & $88.88 \mathrm{a}$ & $12.52 \mathrm{~b}$ & $6.44 \mathrm{~b}$ \\
Un inoculated (control) & $0 \mathrm{c}$ & $0 \mathrm{~d}$ & $100 \mathrm{a}$ & $16.83 \mathrm{a}$ & $18.67 \mathrm{a}$ \\
\hline
\end{tabular}


Pathogenicity trail of potted wheat plant in greenhouse.

Results of pathogenicity test in greenhouse revealed that all tested species of Fusarium caused worthwhile infection of wheat seedlings with diagnostic symptoms of stunting seedlings, seedling blight, rotting of roots and crown. The most virulent was F. oxysporum (0.78) with no significant effect of F. solani and
F. graminearum. The low disease severity was (0.16) caused by F. udum (Table 2). Root length of wheat seedling was reduced and the most affected fungus was F. oxysporum $(0.83 \mathrm{~cm})$ that was significantly varied from all other tested species. Seedling height was also reduced with significant difference from control treatment except F. udum.

Table 2. Pathogenicity test of isolated fungi and there effect on seedling height and root length under greenhouse conditions.

\begin{tabular}{lccc}
\hline Fungi & $\begin{array}{c}\text { Disease } \\
\text { severity }\end{array}$ & $\begin{array}{c}\text { Seedling } \\
\text { height }(\mathbf{c m})\end{array}$ & $\begin{array}{c}\text { Root } \\
\text { length }(\mathbf{c m})\end{array}$ \\
\hline F. graminearum & $0.66 \mathrm{ab}$ & $20.5 \mathrm{~b}$ & $4.83 \mathrm{ab}$ \\
F. oxysporum & $0.78 \mathrm{a}$ & $20.66 \mathrm{~b}$ & $0.83 \mathrm{c}$ \\
F. solani & $0.70 \mathrm{ab}$ & $24 \mathrm{~b}$ & $3.66 \mathrm{~b}$ \\
F. avenaceum & $0.54 \mathrm{bc}$ & $21.16 \mathrm{~b}$ & $3.91 \mathrm{~b}$ \\
F. nivale & $0.45 \mathrm{c}$ & $24.83 \mathrm{~b}$ & $4.91 \mathrm{ab}$ \\
F. udum & $0.16 \mathrm{~d}$ & $25.91 \mathrm{ab}$ & $5 \mathrm{ab}$ \\
Control & $0 \mathrm{~d}$ & $31.66 \mathrm{a}$ & $6.5 \mathrm{a}$ \\
\hline
\end{tabular}

\section{Pathogenicity trial of potted wheat plant in the} field

Pathogenicity trial under field condition showed the diagnostic symptoms of Fusarium Crown and Root
Rot include dark brown to black lesion on root, sub crown internode and stem bases forming large area of dead tissue in crown (Figure 1).

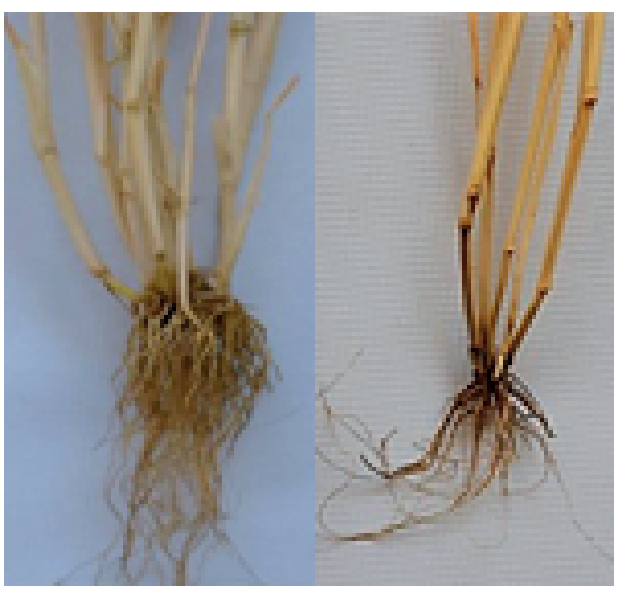

Figure 2. Symptoms of FCRR disease on wheat resulted from pathogenicity test in the field showing extend in browning and rotting of root, crown and stem (1: Healthy plant, 2: Infected plant). 
Field experiment demonstrated that disease severity in ripening stagewas more obvious than in booting stage on both cultivars (Simeto and Sham 6) (Table 3). The most virulent fungus was $F$. graminearum $(0.42)$ that was significantly different from others.
There was no significant difference between F. oxysporum and F. solani. Whereas the effect of fungi on tested cultivar showed that in both stages of wheat growth durum wheat (Simeto) cultivar was more affected by fungi than soft (Sham6) cultivar.

Table 3. Pathogenicity trial of potted wheat plants in the field.

\begin{tabular}{llccc}
\hline \multicolumn{1}{c}{ Cultivars } & \multicolumn{1}{c}{ Fungi } & Booting stage & Ripening stage & Effect of cultivars \\
\hline \multirow{3}{*}{ Simeto } & F. graminearum & $0.28 \mathrm{~cd}$ & $0.49 \mathrm{a}$ & $0.38 \mathrm{a}$ \\
& F. oxysporum & $0.23 \mathrm{de}$ & $0.41 \mathrm{ab}$ & $0.32 \mathrm{~b}$ \\
& F. solani & $0.18 \mathrm{e}$ & $0.37 \mathrm{~b}$ & $0.27 \mathrm{~b}-\mathrm{d}$ \\
& Healthy plant & $0 \mathrm{f}$ & $0 \mathrm{f}$ & $0 \mathrm{e}$ \\
Cham6 & F. graminearum & $0.20 \mathrm{de}$ & $0.36 \mathrm{bc}$ & $0.28 \mathrm{bc}$ \\
& F. oxysporum & $0.16 \mathrm{e}$ & $0.28 \mathrm{~cd}$ & $0.22 \mathrm{~cd}$ \\
& F. solani & $0.15 \mathrm{e}$ & $0.28 \mathrm{~cd}$ & $0.22 \mathrm{~cd}$ \\
Effect of & Healthy plant & $0 \mathrm{f}$ & $0 \mathrm{f}$ & $0 \mathrm{e}$ \\
stages & F. graminearum & $0.24 \mathrm{c}$ & $0.42 \mathrm{a}$ & $* * * * * * * * *$ \\
& F. oxysporum & $0.19 \mathrm{~cd}$ & $0.34 \mathrm{~b}$ & \\
\hline
\end{tabular}

\section{DISCUSSION}

Results of test tube method revealed that wheat seed germination was consistent with the results of other workers who demonstrated that infected wheat seeds with Fusarium spp. is often associated with reduced germination, seedling vigor $\stackrel{(25,26)}{ }$ and emergence ${ }^{(27)}$. The highest disease incidence reflected the lowest germination rate, and the least disease incidence gave the highest germination rate $\stackrel{(28)}{ }$. When seeds germinate and root tips elongate, nutrients exudate, stimulating the fungal spores to germinate and growth of infection hyphae to penetrate plant tissues. Before or soon after emergence affected seedlings may die even if they are weakly affected (29.30). Results of pathogenicity test was in line with Brennan et al. (2003) ${ }^{(31)}$ who proved that generally F. graminearum was more pathogenic than $F$. avenaceum and F. nivale, and with result of pathogenicity test of F. solani done by Matnyet al. ${ }^{(32)}$. Also similar results reported by Wang $\stackrel{(33)}{ }$ who showed that successful invasion of wheat roots by F. graminearum produced adverse effect on the root and seedling growth, after 14 days of inoculation half of tested wheat plants were wilted.
Under greenhouse condition, the results were in line with Kane et al. ${ }^{(34)}$ who recorded that F. graminearum was more aggressive in causing pre and post emergence seedling mortality than F. avenaceum, while both fungi reduced number of tillers and grain yield. Also Fernandez and Chen (2005) graminearum was more pathogenic as crown rot to $F$. avenaceum in greenhouse conditions. Gargouri-Kammounet al. ${ }^{(12)}$ reported that F. graminearum produced highest disease severity, while F. avenaceum and F. nivale were weak pathogenic species under controlled conditions.

In contrast to our results, Jenkinson and Parry ${ }^{(36)}$ and Arseniuket al. ${ }^{(37)}$ recorded that $F$. avenaceum was as, or more, pathogenic than F. culmorum and F. graminearum to wheat seedlings, while Specht and Rush (38) reported that $F$. avenaceum produced no mortality to winter wheat.

Through a pathogenicity test on wheat roots, Hajieghrari ${ }^{(39)}$ revealed that F. graminearum, F. udumand $F$. solani are involved in destruction of wheat root tissues. Gordon et al. $\stackrel{(40)}{\longrightarrow}$ demonstrated that F. oxysporum and F. solani are wheat root colonizers during a 
pathogenicity test performed in the greenhouse.

Under Field conditions, result was in agreement with the result of Chekali et al. ${ }^{(41)}$ who revealed that soft wheat and durum wheat cultivars grown in Tunis seem to be susceptible to disease but soft wheat cultivars had a partial resistance. Our result was corresponding to the result of other workers who showed that damage of disease severity of crown rot is highly affected by plant stress as reach to the maturity stage, because maturation of wheat occurs in midsummer when temperature is high and water available in the soil is limited ${ }^{(42,43)}$. Also Covarelli et al. ${ }^{(44)}$ recorded that after inoculation of Fusarium spp. to the base of wheat seedlings, symptoms of disease appeared at the stem base and reached to upper nods when plant reached to maturity. Paulitzet al. ${ }^{(1)}$ revealed that after dry climate during anthesis and ripening severity of crown rot is increased. Infection the crown and root might then be a source of inoculum for infection of heads the following seasons or might constitute a significant fungal survival mechanism under dry conditions.

\section{CONCLUSION}

We conclude that Fusarium graminearum, F. oxysporum and F. solani, the causes of crown and root rot of wheat, were highly virulent and more pathogenic than remaining tested species under three conditions (Laboratory, Greenhouse and Field condition). Additionally, our results indicated that Test tube method in laboratory is simple, rapid and reliable method for pathogenicity studies of Fusarium species.

\section{REFERENCES}

1. Paulitz T. C., Smiley R. W. and Cook R. J. Insights into the prevalence and management of soilborne cereal pathogens under direct seeding in the Pacific Northwest, USA. Can. J. of Plant Pathol., 2002; 24(4): 416-428. https://doi.org/10.1080/07060660209507029

2. Burgess L.W., Backhouse D., Summerell B. A. and Swan L. J., Chapter 20 in Fusarium- Paul E. Nelson Memorial Symposium. Edited by Summerell B.A., Leslie J.F., Backhouse D. Bryden W.L and Burgess L.W. APS Press, The American Phytopathological Society, St. Paul, Minnesota, United States of America. 2001; ISBN 0-89054-268-6. pp. 271-294.

3. Cook, R. J., Fusarium root, crown, and foot rots and associated seedling diseases. Compendium of wheat diseases and pests. $3^{\text {rd }}$ ed. The Pennsylvania State University Press, University Park, Pennsylvania, USA, 2010; 37-39.

4. Mergoum, M., Lyamani, A.andNsarellah, N., Root rot of wheat. Al Awamia Magazine National Government publication Morocco,1995; 89:1-24.

5. Nicol, J. M., Bagci, A., Hekimhan, H., Bolat, N., Braun, H. J. and Trethowan, R., Strategy for the identification and breeding of resistance to dry land root rot complex for international spring and winter wheat breeding programs. Page 283 in: Proc. 4th Int. Crop Sci. Congr., Brisbane, Australia, 2004.

6. Beev, G., Denev, S. and Pavlov, D., Occurrence and distribution of Fusarium species in wheat grain. Agricul. Scie. and Technol. 2011; 3(2):165168. 
7. Chakraborty, S., Obanor, F., Westecott, R. and Abeywickrama, K., Wheat crown rot pathogens Fusarium graminearumand F. pseudograminearum lack specialization. Phytopathology, (2010); 100:1057-1065.

https://doi.org/10.1094/PHYTO-01-10-0007

8. Al-Tovi, B.S., Prevalence and Molecular identification of Fusarium Crown and Root Rot of Wheat in Sumel-Duhok Province. M.Sc. Thesis, College of Agriculture, University of Duhok,Kurdistan region-Iraq. 2017.

9. Hameed, M. A., Rana, R. M. and Ali, Z., Identification and characterization of a novel Iraqi isolate of Fusarium pseudograminearum causing crown rot in wheat. Genet. Mol. Res, 2012; 11(2): 13411348. https://doi.org/10.4238/2012.May.15.4

10. Khalifah, M.H., Molecular identification of wheat crown rot pathogen and evaluation of some protective methods. M.Sc. thesis, College of Agriculture, University of Baghdad, Baghdad, Iraq. 2013; (In Arabic).

11. Taha, Z.A., Wheat root rot in Ninevah government and its biological control. M.Sc. thesis, College of Agriculture and Forestry, University of Mosul, Iraq. 2014; (In Arabic).

12. Gargouri-Kammoun, L., Gargouri, S., Rezgui, S., Trifi, M., Bahri, N.andHajlaoui, M. R., .Pathogenicity and aggressiveness of Fusarium and Microdochium on wheat seedlings under controlled conditions. Tunisian J. of Plant Prot., 2009; 4(2):135-144.

13. Brennan, J.M., Fagan, B., van Maanen, A., Cooke, B.M. and Doohan, F.M., Studies on in-vitro growth and pathogenicity of European Fusarium fungi. Eur. Journal of Plant Pathology.(2003); 109: 577587. https://doi.org/10.1023/A:1024712415326

14. Carter, J. P., Rezanoor, H. N., Holden, D., Desjardins, A. E., Plattner, R. D. and Nicholson, P., Variation in pathogenicity associated with the genetic diversity of Fusarium graminearum. Eur. J. of Plant Pathol., 2002; 108(6): 573-583.

https://doi.org/10.1023/A:1019921203161

15. Tunali, B., Nicol, J., YeldaErol, F. and Altiparmak, G., Pathogenicity of Turkish crown and head scab isolates on stem bases on winter wheat under greenhouse conditions. Plant Pathol. J. 2006; 5: 143-149.

https://doi.org/10.3923/ppj.2006.143.149

16. Booth, C., Fusarium, Laboratory guide to the identification of the major species. Common wealth Mycological Institute. Academic press. UK, 1977; ISBN 0851983839.

17.Nelson, P.E., Dignani, M.C. and Anaissie, E.J., Taxonomy, biology, and clinical aspects of Fusarium species. Clinical Microbiology Reviews, 1994;7(4): 479-504. https://doi.org/10.1128/CMR.7.4.479

18. Summerell, B.A., Salleh, B. and Leslie, J.F., A utilitarian approach to Fusarium identification. Plant Disease, 2003; 87(2): 117-128.

https://doi.org/10.1094/PDIS.2003.87.2.117

19.Leslie, J.F. and Summerell, B.A., Techniques and methods. Fusarium laboratory manual. Blackwell Publishing Ltd., Oxford, UK; 2006.

https://doi.org/10.1002/9780470278376

20.Asad, S.I., Shamim. A. and Iftikhar, A., Characterization of Bipolaris sorokiniana isolated from different agro-ecological zones of wheat production in Pakistan. Pakistan. Journal Botany, 2009; 41(1): 301-308.

21. McKinney, H. H., .Influence of soil temperature and moisture on infection of wheat seedlings by Helminthosporium sativum. J. of Agricult. Res., 1923; 26(5), 195-218.

22.Mitter, V., Zhang, M. C., Liu, C. J., Ghosh, R., Ghosh, M. and Chakraborty, S., A high-throughput glasshouse bioassay to detect crown rot resistance in wheat germplasm. Plant Pathology, 2006; 55(3): 433-441.

https://doi.org/10.1111/j.1365-3059.2006.01384.x

23.Zadoks, J. C., Chang, T. T. and Konzak, C. F., A decimal code for the growth stages of cereals. Weed Res., 1974;14(6): 415-421.

https://doi.org/10.1111/j.1365-3180.1974.tb01084.x

24.SAS., SAS/STAT User's Guide, Version 8.2, $1^{\text {st- }}$ printing.Vol. 2. SAS Institute Inc, SAS Campus Drive, Cary, North Carolina, USA, 2003.

25.Bechtel, D. B., Kaleikau, L. A., Gaines, R. L. and Seitz, L. M.,The effects of Fusarium graminearum infection on wheat kernels. Cereal Chemistry, 1985; 62(3):191-197.

26.Akinsanmi, O. A., Mitter, V., Simpfendorfer, S., Backhouse, D. and Chakraborty, S., Identity and pathogenicity of Fusarium spp. isolated from wheat fields in Queensland and northern New South Wales. Aust. J. Agric. Res. 2004; 55: 97-107. https://doi.org/10.1071/AR03090 
27.Humphreys, J., Cooke, B. M. and Storey, T., Effect of seed borne Microdochium nivaleon establishment and grain yield. Plant Varieties and Seeds 1995; 8:107-117.

28.Debnath, M., Sultana, A. and Rashid, A. Q. M. B., Effect of Seed-borne Fungi on the Germinating Seeds and their Bio-control in Maize. Journal of Environ. Sci. and Natural Res., 2012; 5(1):117120. https://doi.org/10.3329/jesnr.v5i1.11564

29.Rodriguez-Galvez, E. and Mendgen, K., .The infection process of Fusarium oxysporum in cotton root tips. Protoplasma, 1995; 189(1-2): 61-72. https://doi.org/10.1007/BF01280291

30.Deacon J. W. and Donaldson S.P., Molecular recognition in the homing responses of zoosporic fungi, with special reference to Phytium and Phytophthora. Mycol Res 1993; 97:1153-1171.

https://doi.org/10.1016/S0953-7562(09)81278-1

31. Brennan, J.M., Fagan, B., van Maanen, A., Cooke, B.M. and Doohan, F.M., Studies on in-vitro growth and pathogenicity of European Fusarium fungi. Eur. J. of Plant Pathol.. 2003; 109: 577-587.

https://doi.org/10.1023/A:1024712415326

32.Matny, O. N., Chakraborty, S., Obanar, F. and ALAni, R. A., Molecular identification of Fusarium spp causing crown rot and head blight on winter wheat in Iraq. J. of Agricult. Technol., 2012; 8(5): 1677-1690.

33.Wang, Q., The pathosystem wheat (Triticum aestivum) root-Fusarium graminearum: complex plant responses and fungal strategies, Ph.D. dissertation, Justus Liebig University Giessen, Germany. 2015.

34.Kane, R. T., Smiley, R. W. and Sorrells, M. E., .Relative pathogenicity of selected Fusarium species and Microdochium bolleyito winter wheat in New York. Plant Dis. 1987; 71:177-181.

https://doi.org/10.1094/PD-71-0177

35.Fernandez, M. R. and Chen, Y., Pathogenicity of Fusarium species on different plant parts of spring wheat under controlled conditions. Plant Dis., 2005; 89(2): 164-169.

https://doi.org/10.1094/PD-89-0164

36.Jenkinson, P. and Parry, D. W., Isolates of Fusarium species from common broadleaved weeds and their pathogenicity to winter wheat. Mycol. Res. 1994; 98:776-780.

https://doi.org/10.1016/S0953-7562(09)81054-X

37.Arseniuk, E., Goral, T. and Czembor, H. J., Reaction of triticale, wheat and rye accessions to graminaceous Fusariums pp. infection at the seedling and adult plant growth stages. Euphytica 1993; 70:175-183.

https://doi.org/10.1007/BF00023757

38.Specht, L. P. and Rush, C. M., Fungi associated with root and foot rot of winter wheat and populations of Cochliobolus sativus in the Texas Panhandle. Plant Dis. 1988; 72:959-963.

https://doi.org/10.1094/PD-72-0959

39.Hajieghrari, B., Wheat crown and root rotting fungi in Moghan area, Northwest of Iran. Afri. J. of Biotechnol., 2009; 8(22):6214-6219.

https://doi.org/10.5897/AJB09.1087

40.Gordon, T. R., Okamoto, D. and Jacobson, D. J. colonization of muskmelon and no susceptible crops by Fusarium oxysporumf. sp. melonis and other species of Fusarium. Phytopathology, 1989; 79(10):1095-1100.

https://doi.org/10.1094/Phyto-79-1095

41. Chekali, S., Gargouri, S., Berraies, S., Gharbi, M.S., Nicol, M.J. and Nasraoui, B., Impact of Fusarium foot and root rot on yield of cereals in Tunisia. Tunisian J. of Plant Protec.t 2013; 8: 75-86.

42.Papendick, R. I. and Cook, R. J., Plant water stress and development of Fusarium foot rot in wheat subjected to different cultural practices. Phytopathology 1974; 64:358-363.

https://doi.org/10.1094/Phyto-64-358

43.Smiley, R. W., Gourlie, J. A., Easley, S. A. and Patterson, L. M., Pathogenicity of fungi associated with the wheat crown rot complex in Oregon and Washington. Plant Dis., 2005; 89(9): 949-957.

https://doi.org/10.1094/PD-89-0949

44.Covarelli, L., Beccari, G., Steed, A. and Nicholson, P., Colonization of soft wheat following infection of the stem base by Fusarium culmorum and translocation of deoxynivalenol to the head. Plant Pathol., 2012; 61(6), 1121-1129.

https://doi.org/10.1111/j.1365-3059.2012.02600.x 